\title{
Renal small B-cell lymphoma with plasmacytic differentiation presenting with monoclonal gammopathy and disseminated intravascular coagulation syndrome
}

\author{
Paula de Oliveira Pádua Prestes ${ }^{a}$, Carolina Toniolo Zenatti ${ }^{b}$, \\ Luiz Felipe Adsuara de Sousa ${ }^{a}$, Artur Chinen Nagamine ${ }^{c}$, Aloísio Felipe-Silva ${ }^{d}$
}

Prestes POP, Zenatti CT, Sousa LFA, Nagamine AC, Felipe-Silva A. Renal small B-cell lymphoma with plasmacytic differentiation presenting with monoclonal gammopathy and disseminated intravascular coagulation syndrome. Autopsy Case Rep [Internet]. 2013; 3(3): 31-40. http://dx.doi.org/10.4322/acr.2013.026

\section{ABSTRACT}

Primary renal lymphomas are very rare. However, the kidney may be a site of metastasis, usually from a disseminated aggressive lymphoma. A 58-yearold woman was brought to the medical facility due to acute mental confusion, severe hypotension, septic shock, and signs of disseminated intravascular coagulation. Laboratory tests showed severe leukopenia, renal failure, altered liver function, and elevated serum lactate dehydrogenase levels. Protein electrophoresis revealed hypergammaglobulinemia with a monoclonal peak of IgG lambda. The clinical outcome was fulminant and the patient died less than 24 hours after admission. Autopsy revealed an indolent B-cell lymphoma with extensive plasmacytic differentiation infiltrating the right renal sinus and involving the submandibular and sublingual glands, cervical and peri-aortic lymph nodes, multiple microscopic foci in pituitary and adrenal glands, lung, breast, liver, thyroid, and bone marrow. Numerous IgG4-positive plasma cells were detected by immunohistochemistry although other histological features of IgG4-related disease were missing. There was also extensive hemorrhagic necrosis of the adrenal glands and purulent cystitis, which was probably responsible for the septic shock. The authors concluded that the kidney was most likely the primary site of the indolent lymphoma, as that was the site with the largest tumor mass. Infiltration of other organs was considered as dissemination of the disease. The differential diagnosis with mucosaassociated lymphoid tissue and lymphoplasmacytic lymphoma is discussed.

Keywords: Lymphoma; Kidney; Lymphoma, B-Cell, Marginal Zone; Immunoglobulin G; Pyelonephritis; Shock, Septic; Waterhouse-Friderichsen Syndrome; Autopsy.

\footnotetext{
a Department of Internal Medicine - Hospital das Clínicas - Faculdade de Medicina - Universidade de São Paulo, São Paulo/SP - Brazil.

${ }^{\mathrm{b}}$ Instituto de Infectologia Emílio Ribas, São Paulo/SP - Brazil.

c Physical Medicine and Rehabilitation Department - Hospital das Clínicas - Faculdade de Medicina - Universidade de São Paulo, São Paulo/SP - Brazil.

d Anatomic Pathology Service - Hospital Universitário - Universidade de São Paulo, São Paulo/SP - Brazil.
}

Copyright $\odot 2013$ Autopsy and Case Reports - This is an Open Access article distributed of terms of the Creative Commons Attribution NonCommercial License (http://creativecommons.org/licenses/by/3.0/) which permits unrestricted non-commercial use, distribution, and reproduction in any médium provided article is properly cited. 


\section{CASE REPORT}

A 58-year-old woman previously diagnosed with hypertension, who was regularly taking losartan, hydrochlorothiazide, and propranolol, was brought to the emergency room by her family who reported a 1-day history of watery diarrhea, abdominal pain, and vomiting, followed by mental confusion and fever. She had a past history of acute pyelonephritis caused by multi-sensitive $E$. coli.

On physical examination, the patient was pale and dehydrated with a normal respiratory pattern. Blood pressure was $90 / 58 \mathrm{mmHg}$, pulse rate 130 beats per minute, respiratory rate 20 breaths per minute, axillary temperature $36{ }^{\circ} \mathrm{C}$, room air oximetry $93 \%$, and blood glucose of $68 \mathrm{mg} / \mathrm{dL}$. On neurological examination the patient showed mental confusion, but neither motor deficit signs nor meningeal irritation were disclosed. Pupils were isochoric and reactive to light. Examination of the lungs and heart were normal. The abdomen was distended and diffusely painful, but the rebound sign was negative; liver was palpable until $3 \mathrm{~cm}$ below the right costal margin. The initial laboratory workup is shown in Table 1.

The patient was submitted to volemic resuscitation simultaneously with a prescription of ceftriaxone and metronidazole focusing the clinical hypothesis of abdominal sepsis due to acute gastroenteritis. The clinical outcome worsened during the following hours with severe hypotension, poor peripheral perfusion, tachycardia, and blood glucose determination of $15 \mathrm{mg} / \mathrm{dL}$. Petechiae emerged on the trunk and spontaneous bleeding was observed from oral and nose mucosa, as well as from venipuncture sites.

Despite the mechanical ventilatory support and the attempt of hemodynamic stabilization with intravenous norepinephrine, the patient died 7 hours after admission. Serum protein electrophoresis undertaken postmortem revealed a hypergammaglobulinemia of $2.85 \mathrm{~g} / \mathrm{dL}$ (RV: $0.5-1.6 \mathrm{~g} / \mathrm{dL}$ ) with a monoclonal peak of IgG lambda. Blood culture was negative while the culture of urinary bladder contents collected at autopsy was positive for multiresistant Klebsiella pneumoniae and Enterobacter cloacae complex, which were interpreted as probable contaminants.

\section{Autopsy Findings}

Gross examination of the cephalic segment showed a congested brain, pituitary gland hyperplasia exhibiting a reddish surface (Figure 1), cervical lymphadenomegaly with lymph nodes measuring up to $1.8 \mathrm{~cm}$ at the longest axis, and enlarged submandibular and sublingual glands.

Small bilateral yellowish pleural effusion was disclosed at the chest cavity opening. The right lung weighed $636 \mathrm{~g}$ (RV: $450 \mathrm{~g}$ ) and left lung $598 \mathrm{~g}$ (RV: $375 \mathrm{~g})$ and showed up wine-colored, with marked

Table 1 - Initial laboratory workup

\begin{tabular}{cccccc}
\hline Exam & Result & RV & Exam & Result & RV \\
\hline Hemoglobin & 11.9 & $12.3-15.3 \mathrm{~g} / \mathrm{dL}$ & Creatinine & 3.7 & $0.4-1.3 \mathrm{mg} / \mathrm{dL}$ \\
Hematocrit & 36.6 & $36.0-45.0 \%$ & Sodium & 140 & $136-146 \mathrm{mEq} / \mathrm{L}$ \\
Leukocytes & 1180 & $4.4-11.3 \times 10^{3} / \mathrm{mm}^{3}$ & Potassium & 3.0 & $3.5-5.0 \mathrm{mEq} / \mathrm{L}$ \\
Myelocytes & 4 & 0 & AST & 116 & $10-31 \mathrm{U} / \mathrm{L}$ \\
Metamyelocytes & 8 & 0 & ALT & 25 & $9-36 \mathrm{U} / \mathrm{L}$ \\
Bands & 21 & $1-5 \%$ & Total bil & 2.1 & $0.3-1.2 \mathrm{mg} / \mathrm{dL}$ \\
Segmented & 34 & $46-75 \%$ & Direct bil & 1.5 & until $0.2 \mathrm{mg} / \mathrm{dL}$ \\
Eosinophils & 2 & $1-4 \%$ & Albumin & 2.7 & $3.0-5.0 \mathrm{~g} / \mathrm{dL}$ \\
Basophils & 1 & $0-2.5 \%$ & (PT) INR & 4.59 & 1 \\
Lymphocytes & 26 & $18-40 \%$ & R (ATPT) & 4.43 & until 1.25 \\
Monocytes & 4 & $2-9 \%$ & Cai & 1.07 & $1.15-1.35 \mathrm{mmol} / \mathrm{L}$ \\
Platelets & 28100 & $150-400 \times 10^{3} / \mathrm{mm}^{3}$ & Lactate & 97.7 & $3.0-13.2 \mathrm{mg} / \mathrm{dL}$ \\
Urea & 83 & $10-50 \mathrm{mg} / \mathrm{dL}$ & CRP & 262 & $<5.0 \mathrm{mg} / \mathrm{L}$ \\
\hline
\end{tabular}

ALT = alanine aminotransferase; AST = aspartate aminotransferase; ATPT = activated thromboplastin time; bil = bilirubin; Cai = ionized calcium; $\mathrm{CRP}=\mathrm{C}$-reactive protein; INR = international normalized ratio; $\mathrm{PT}=$ prothrombin time; $\mathrm{R}=$ ratio; $\mathrm{RV}=$ reference value. 

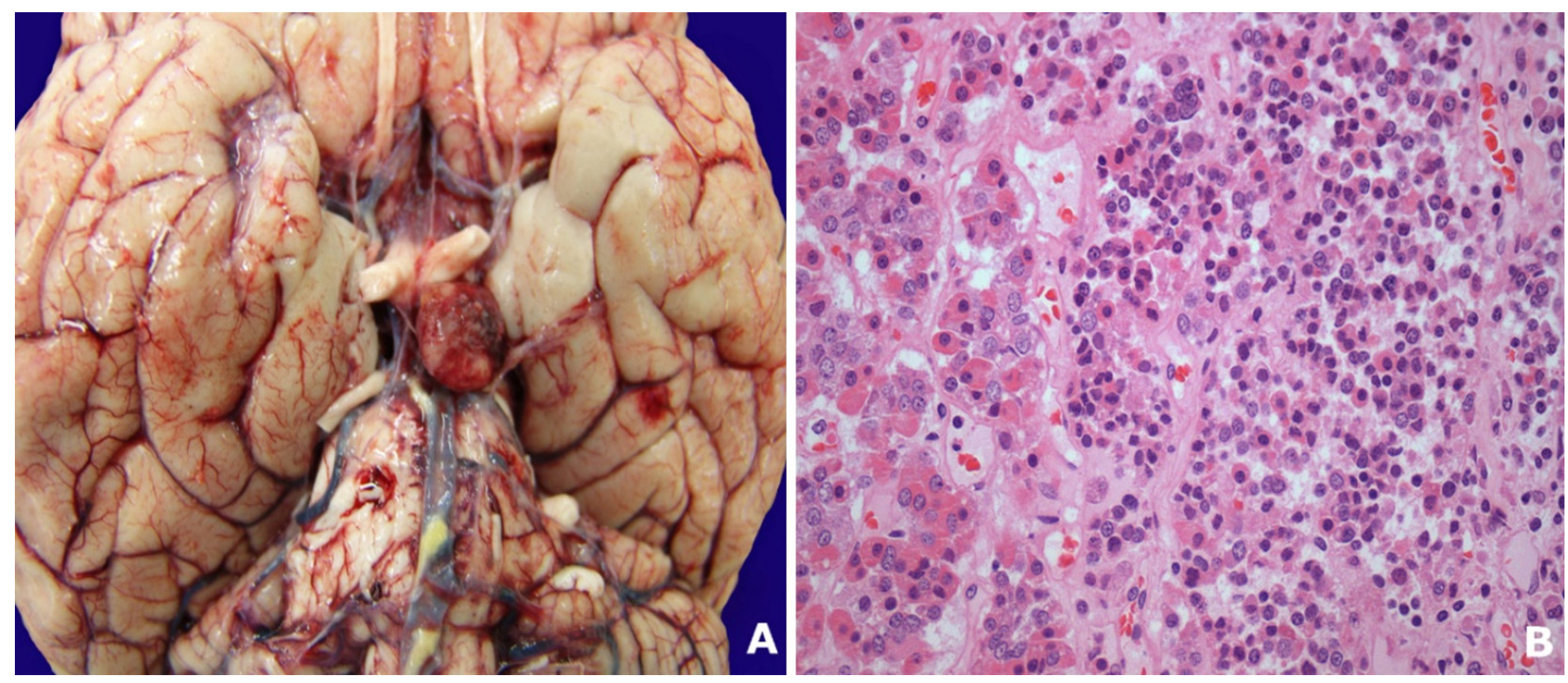

Figure 1 - A - Gross view of the base of the encephalon, showing the enlarged and congested pituitary gland; B - Photomicrography of the pituitary tissue (left) infiltrated by plasmocitoid cells (right) (H\&E; 400x).

edema more pronounced in the lower lobes. The pericardial sac opening showed the presence of small yellow-citrine effusion. The heart weighed $336 \mathrm{~g}$ (RV: $262 \mathrm{~g}$ ) with moderate concentric left ventricular hypertrophy.

At the opening of the abdominal cavity, the spleen was mildly enlarged and periaortic lymphadenopathy was detected (lymph nodes measured up to $3 \mathrm{~cm}$ at the longest axis). The left kidney weighted $178 \mathrm{~g}$ and the right kidney $284 \mathrm{~g}$ ( $\mathrm{RV}$ for both kidneys: $288 \mathrm{~g}$ ), both presenting simple cysts measuring less than $2 \mathrm{~cm}$ each. The kidneys cut-section showed foci of hemorrhage in the corticomedullary transition, bilaterally. Diffuse thickening of the sinus, and intense infiltration of the right renal pelvis by a white tissue of imprecise limits extending to the renal cortex and measuring $8.0 \mathrm{~cm}$ at its longest axis, characterized the gross examination of the right kidney (Figure 2). The ureters were preserved. The urinary bladder showed mucosal hyperemia containing purulent content (Figure $3 \mathrm{~A}$ ). The adrenal glands showed a bilateral hemorrhagic aspect (Figure 3B).

The cause of death was attributed to septic shock of urinary origin, accompanied by disseminated intravascular coagulation and hemorrhagic necrosis of the adrenals, clinically known as Waterhouse-Friderichsen syndrome.

Microscopic examination of the right kidney showed an infiltrating lymphoid proliferation of small and monotonous lymphocytes with extensive plasmacytic differentiation. Immunohistochemistry showed that the lymphocytes were positive for CD20, CD138+, and cytoplasmic monotypic lambda light chain, and negative for CD3, CD5, $\mathrm{CD} 23$, and cyclin D1. The proliferation index, as assessed by Ki67, was approximately $5 \%$. The tumor was classified as small B-cell lymphoma with extensive plasmacytoid differentiation, most likely an extranodal marginal zone lymphoma of the mucosa-associated lymphoid tissue (MALT), although lymphoplasmacytic lymphoma (LPL) could be an important differential diagnosis. The same cellular pattern was found infiltrating submandibular and sublingual glands (Figure 4) with some periductular fibrosis but neither obliterative phlebitis nor typical lymphoepithelial lesions were detected. Monotonous lymphoplasmacytic infiltration was also seen in abdominal and cervical lymph nodes (Figure 5), and the pituitary gland. Curiously, immunohistochemistry showed numerous IgG4positive plasma cells (more than 50 per high-power field) in the kidney and lymph nodes, with a ratio of IgG4 to IgG higher than 50\% (Figure 6). However, storiform fibrosis, obliterative phlebitis, eosinophils, and other histopathological signs of IgG4-related disease were not detected. Microscopic foci of lymphoplasmacytic infiltrates were detected in the adrenal glands, lungs, liver, breast, and thyroid. Bone marrow had a mild multifocal interstitial infiltration pattern but with fewer plasma cells. The spleen was not infiltrated and showed reactive changes related to sepsis. The stomach, pancreas and gastrointestinal $(\mathrm{Gl})$ tract showed signs of shock and hypoxia related to sepsis, but lymphoplasmacytic infiltration was not detected. 


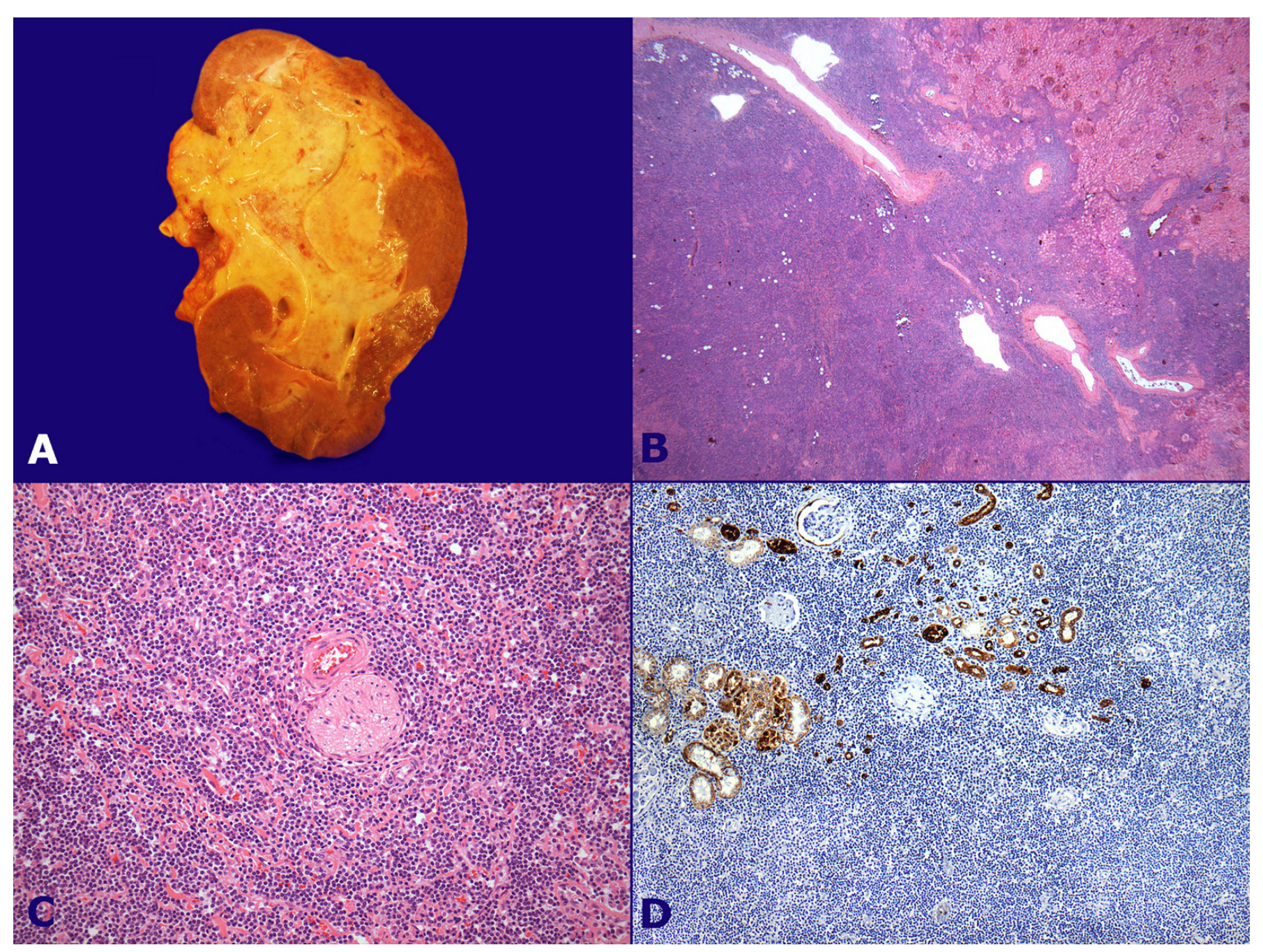

Figure 2 - A - Gross view of the right kidney showing hilar infiltration by a white, soft, poorly circumscribed tumoral mass. Photomicrography of the renal tissue: B - Diffuse infiltration of the renal tissue by a small cell lymphoma (H\&E, 100x); C - Lymphoma infiltration around kidney arteries and nerves (H\&E, 200x); D - Immunohistochemistry for AE1+AE3 (pan-keratin) showing residual atrophic tubular structures (AE1+AE3, 200x).
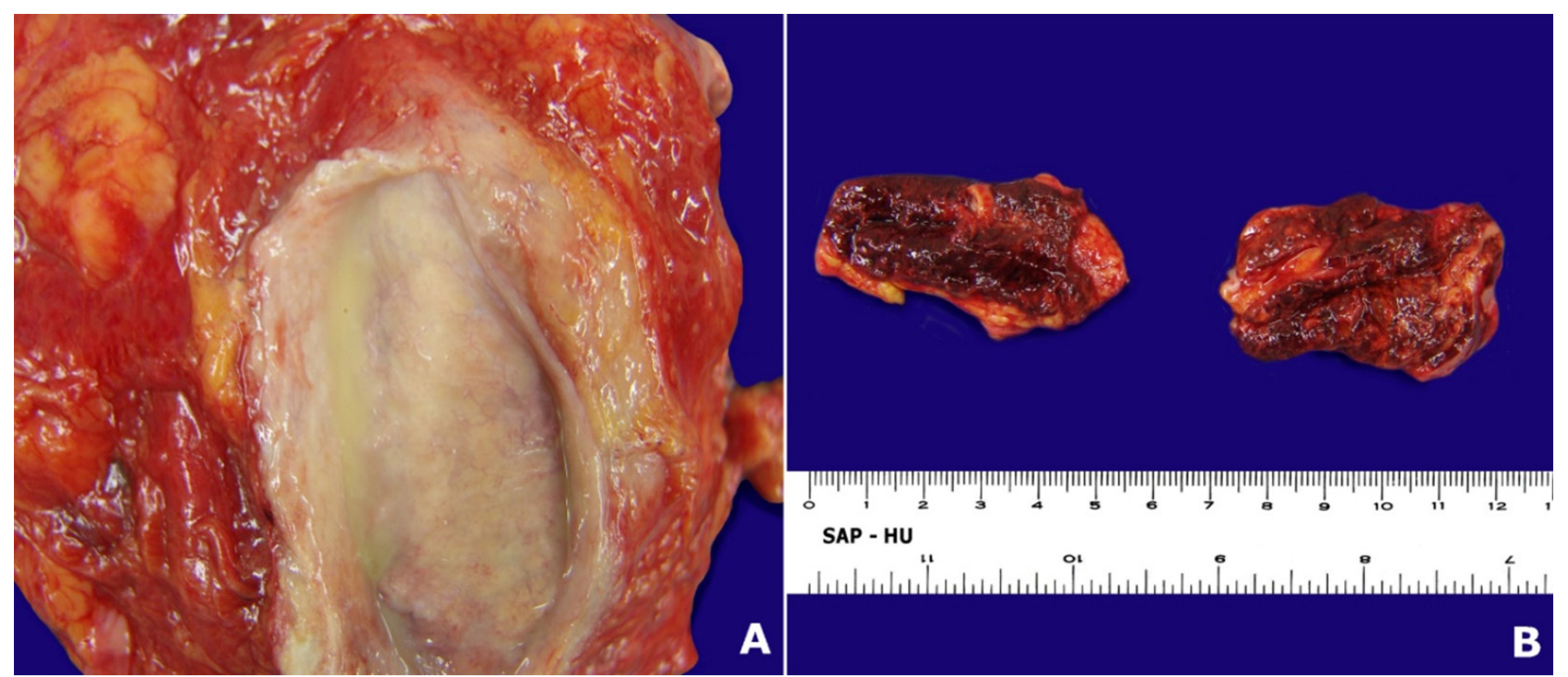

Figure 3-A - Gross view of the opened urinary bladder with yellowish purulent content; B - Gross view of the hemorrhagic bilateral adrenal glands. 


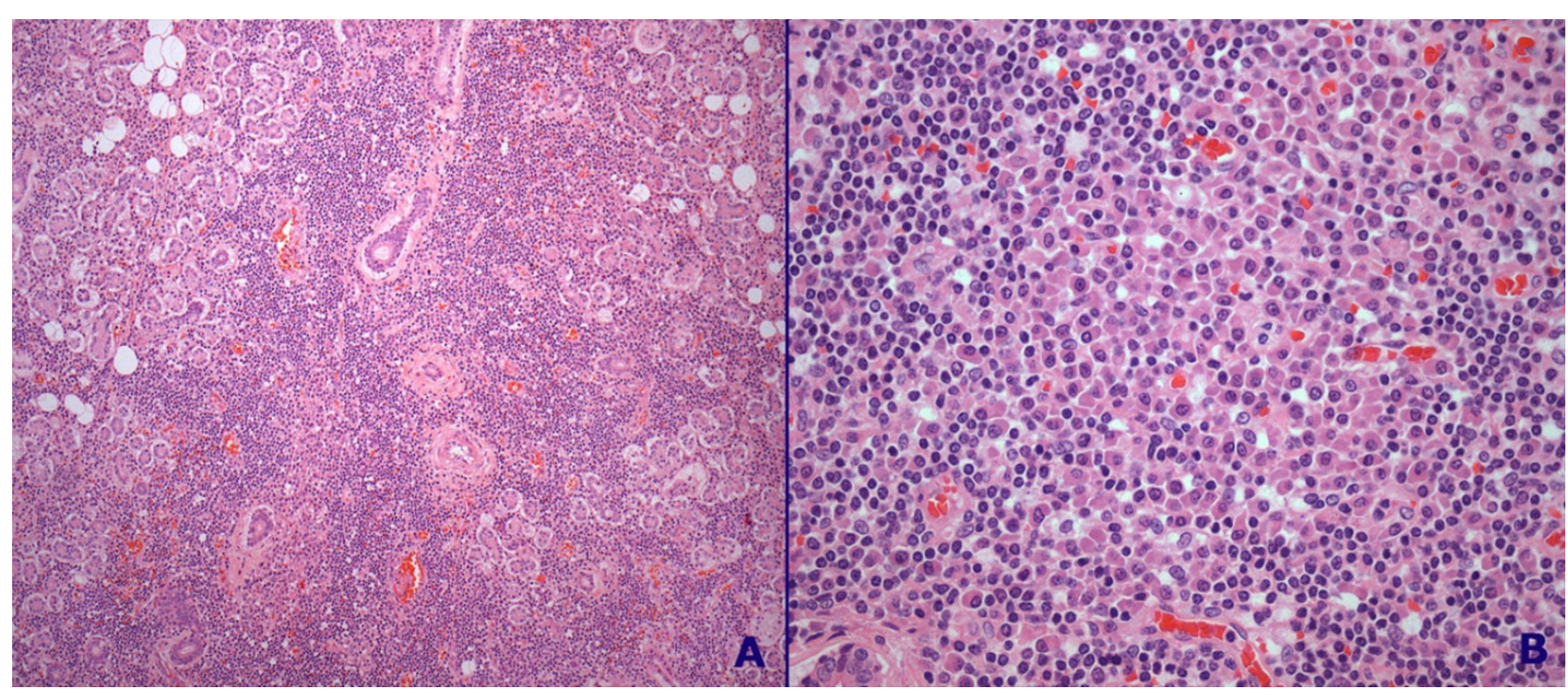

Figure 4 - Photomicrography of the submandibular gland. A - Infiltrated submandibular gland with some atrophic ductular structures and mild periductular fibrosis (H\&E, 200x); B - Areas of plasmacytic differentiation (H\&E, 400x).

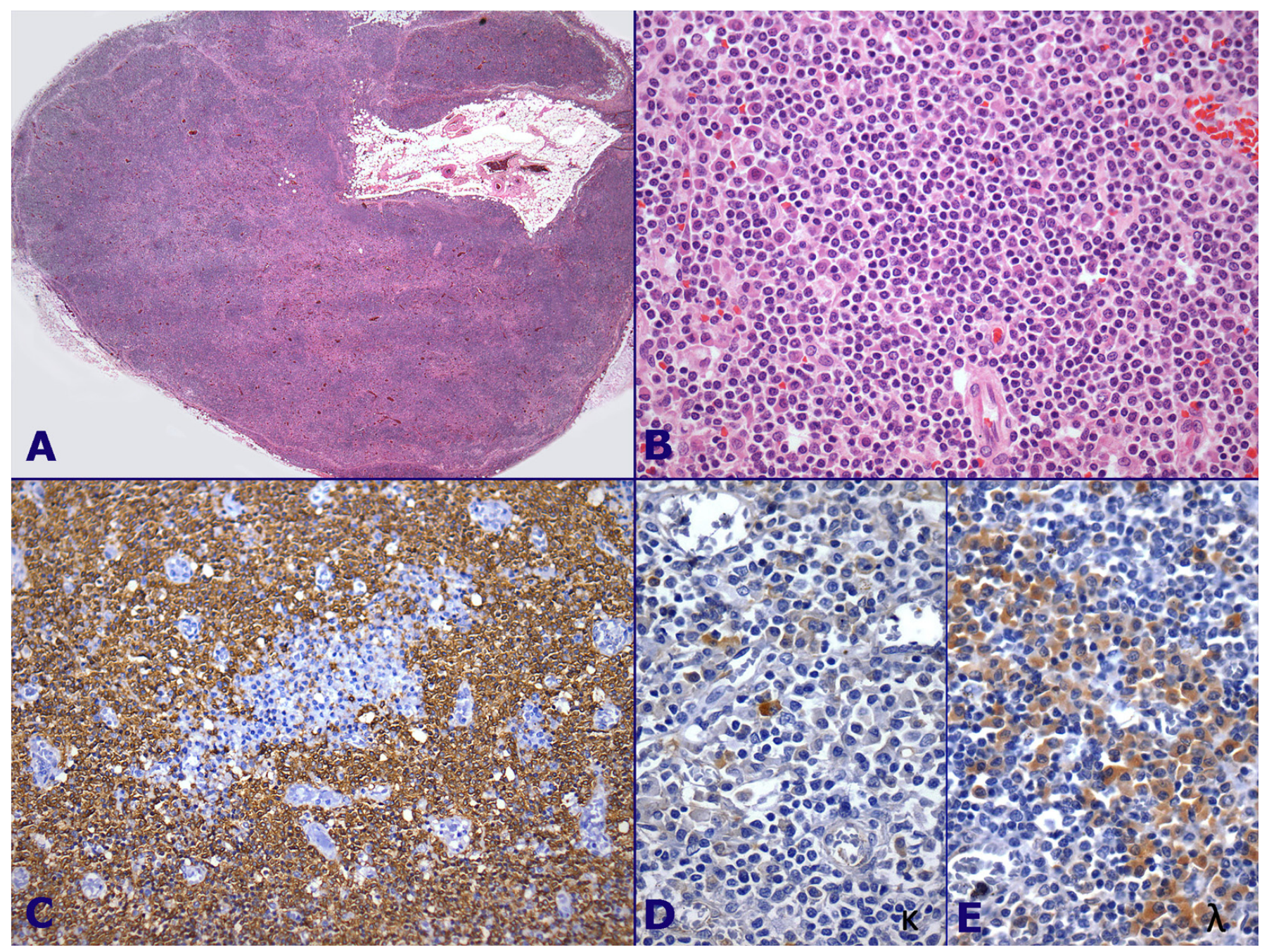

Figure 5 - Photomicrography of lymph node. A - Abdominal lymph node with architectural effacement (H\&E, 25x); B - Small B cell lymphoma with monotonous small lymphoid cells and some plasma cells (H\&E, 400x); C - Immunohistochemistry for CD20 demonstrating B cells (brown) (400x); D - Immunohistochemistry for kappa and $\mathbf{E}$ - lambda light chain demonstrating cytoplasmatic staining in plasma cells (400x). 


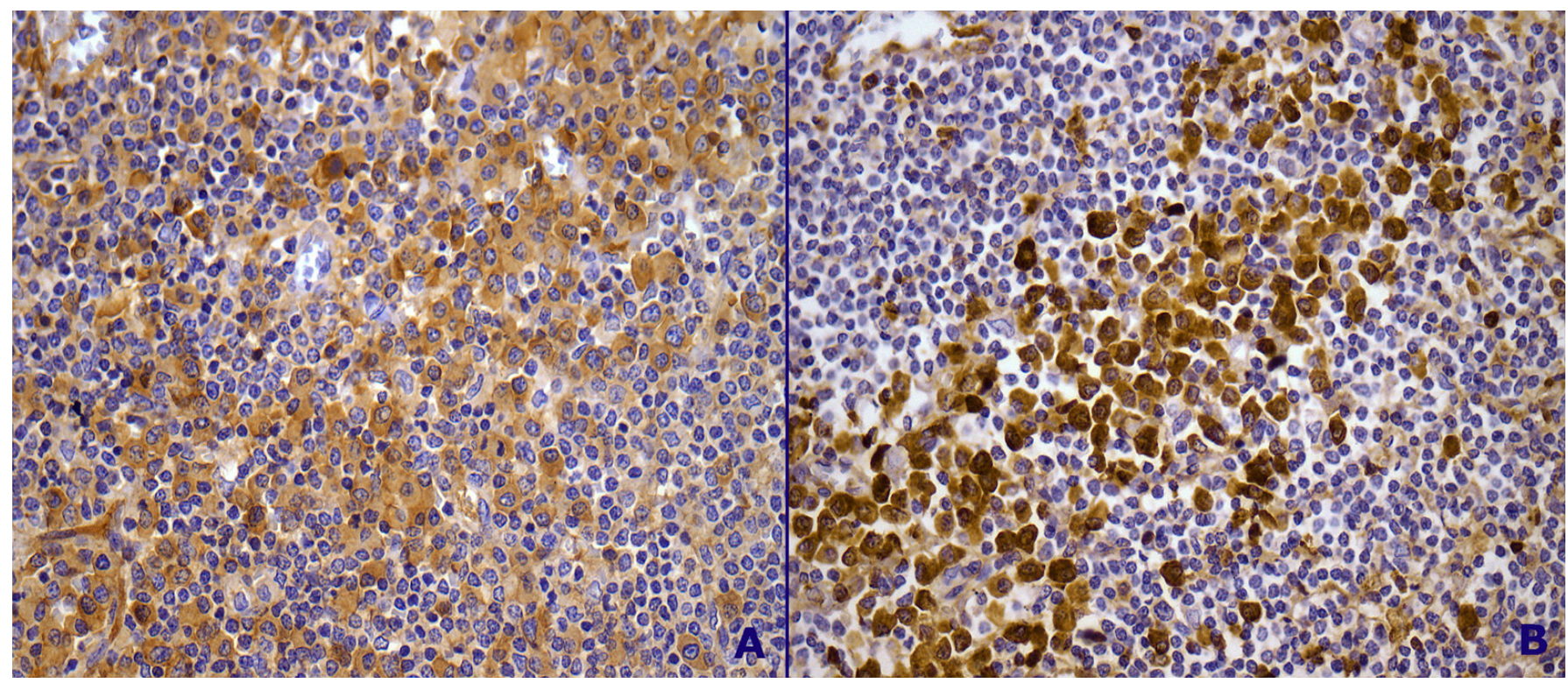

Figure 6 - Immunohistochemistry for immunoglobulins. A - Plasma cells expressing IgG in the lymph node (400x); B - Plasma cells expressing lgG4 in the kidney (400x).

\section{DISCUSSION}

This case most likely represents a primary renal MALT lymphoma with extensive plasmacytic differentiation. LPL is an important and sometimes difficult differential diagnosis, which warranted, in this case, the descriptive diagnosis of small B-cell lymphoma with plasmacytic differentiation. All types of marginal zone lymphomas (MZL) - MALT type, splenic, and nodal-may show prominent plasmacytic differentiation. Differentiating marginal zone lymphomas from other small B-cell lymphomas with plasmacytic differentiation, especially LPL or from plasma cell neoplasms, may be a difficult task. ${ }^{1,2}$

MALT lymphomas, first described by Isaacson and Wright $^{3}$ represent $7-8 \%$ of non-Hodgkin lymphomas and have specific clinicopathological features. ${ }^{4}$ The $\mathrm{Gl}$ tract is the most commonly affected site, which is involved in two-thirds of cases, with the stomach being the most common location (85\%). However, any extranodal anatomic site can be involved with MALT lymphoma, including lung $(14 \%)$, ocular adnexa (12\%), skin (11\%), thyroid $(4 \%)$, breast $(4 \%)$, salivary glands, bladder, and more rarely, the kidneys. ${ }^{5-7}$

MZL occurs mainly in the sixth decade of life and presents a slight female predominance (male:female ratio $=1: 1.2){ }^{1,7}$ Despite the overlap of morphological features, the distinction between nodal and extranodal marginal B-cell lymphoma is clinically important, since their clinical behavior is distinct. $^{8}$

Due to an interaction between the lymphoma cells and mucosal adhesion molecules, ${ }^{9,10}$ the MALT lymphomas remain localized in their primary site for a long time. ${ }^{11,12}$ Dissemination to multiple organs is not uncommon, occurring in over $25 \%$ of cases of gastric MALT lymphoma and $45 \%$ of extragastric cases. ${ }^{4,6}$ Unlike its nodal counterpart, the extranodal MALT lymphoma shows a less aggressive course, presenting as a slow-growing mass or diffuse submucosal thickening that can be mistaken for a benign inflammatory process or "pseudo lymphoma". The 5-year survival is generally greater than $85 \%$, even with multifocal involvement. ${ }^{8}$

The extranodal MZL arises in organs (e.g. stomach, lung, salivary glands, and lacrimal glands) that normally are free of lymphoid tissue but can accumulate lymphoid B-cells in response to autoimmune disorders or chronic infections. ${ }^{2,13}$ The latter may occur secondary to chronic infection by Helicobacter pylori, Borrelia burgdorferi and Chlamydia psittaci in the stomach, skin, and eye, respectively. Chronic autoimmune entities related to extranodal MZL comprises Hashimoto's thyroiditis, sialadenitis associated (or not) to Sjoegren's syndrome, systemic lupus erythematosus, and sarcoidosis. , $8,14-21$ In the present case, it is suspected that chronic pyelonephritis triggered the development of the 
lymphoma in the renal pelvis, similar to other authors' descriptions. ${ }^{22-24}$

Notwithstanding the rarity, we inferred the kidney as the primary site of the present case since it represented the location of the largest tumor mass. Another point in favor of dissemination from the kidney to other sites was the absence of chronic inflammatory conditions in all organs except the kidney. However, we cannot rule out the possibility of the occurrence of multicentric lesions, which can occur in MALT lymphomas. ${ }^{4}$ Approximately $25 \%$ of patients with gastric MALT lymphoma and $45 \%$ of patients with extragastric MALT Iymphoma have multiple sites of disease at the time of the diagnosis..$^{25,26}$ It is frequently assumed as dissemination of the disease when multiple sites of MALT lymphoma are present at the time of the diagnosis. However, many studies explored the clonal relationship of multiple MALT lymphomas by the polymerase chain reaction of the immunoglobulin heavy chain $(\mathrm{IgH})$ gene rearrangement, but the results are controversial. Konoplev et al. ${ }^{4}$ analyzed the $\mathrm{lgH}$ gene rearrangement in four patients with multifocal disease. In three of those patients, the neoplastic clones were distinct and unrelated. These observations suggest that multifocal sites in MALT Iymphoma may not be equivalent to disease dissemination.

Different chromosomal/genotype alterations found in neoplasias that arise in different sites corroborate the hypothesis of multicentricity. The translocation $\mathrm{t}(11 ; 18)(\mathrm{q} 21 ; \mathrm{q} 21)$ is the most common, found most often in MALT lymphomas of the lung and stomach. In contrast, chromosomal abnormalities $\mathrm{t}(14 ; 18)(q 32 ; q 21), \mathrm{t}(1 ; 14)(p 22 ; q 32)$, and $\mathrm{t}(3 ; 14)$ (p14.1;q32) are more common in all other sites of this disease. The $t(14 ; 18)$ is most characteristic in MALT lymphomas of the orbit, skin, and salivary glands. The $t(1 ; 14)$ is rare, but is most commonly found in the intestinal MALT. The $t(3 ; 14)$ is more often present in the lymphomas of the thyroid, skin, and orbit. ${ }^{4}$ This analysis was not performed in this case, so it was not possible to differentiate between a disseminated and a multicentric disease with certainty.

There are some cases in which the MALT lymphoma may present recurrent manifestations at the primary site, with potential for dissemination and progression of high-grade B-cell lymphoma. Involvement of lymph nodes and bone marrow seem to be related to this worse prognosis. ${ }^{6,25}$
The lymphoma cells express surface monotypic immunoglobulins, or, more rarely, cytoplasmic immunoglobulin, usually lgM. Additionally, monoclonal gammopathy is a common phenomenon in MALT Iymphoma, most likely due to paraprotein production by clonal lymphoplasmacytic cells. ${ }^{8,26,27}$ Approximately one-third of extragastric MALT lymphomas have extensive plasma cell differentiation, which permits the differential diagnosis with plasmacytomas or lymphoplasmacytic lymphomas. In the case reported here, the monoclonal IgG lambda was shown by immunohistochemistry and confirmed by serum protein electrophoresis and immunofixation.

The present case represents an advanced stage in the current MALT lymphoma staging scheme once several sites were already involved at the time of diagnosis. ${ }^{28,29}$ Reports on kidney involvement by MALT Iymphomas are scarce. In 2010, Peces et al. ${ }^{8}$ reported a case of a kidney MALT Iymphoma and after a thorough search in the English literature retrieved 30 other unequivocal cases of B-cell MALT lymphomas involving the kidney. In this series, 12 cases concomitantly exhibited the neoplasia in the kidney and other sites; therefore, the authors considered the difficulty of being able to tell in which organ the lymphoma originated. ${ }^{8}$

Poor prognosis is related to the association with nodal and/or bone marrow dissemination in comparison with patients with multiple organ involvement. The management of advanced stage disease, as in the case reported here, is considerably arduous. In advanced cases, there seems to be no difference between letting the disease follow its natural course and undertaking therapeutic interventions, such as surgery, chemotherapy, and/ or radiotherapy. ${ }^{30,31}$ In a series of 180 treated patients with histologic confirmation of nongastric MALT and a median follow-up of 3.4 years, a relapse, histologic transformation, or the appearance of a second tumor was observed in $40 \%$ of the cases. ${ }^{6}$

The patient of this report presented clinical septic shock and disseminated intravascular coagulation, identified at autopsy, which was the immediate cause of death. The WaterhouseFriderichsen syndrome was most likely secondary to urinary infection and sepsis. Given the history of previous urinary infections and considering the immunocompromised patient, it is possible that the bacterial agents from the urinary system were responsible for the purpura fulminans. The bilateral 
adrenal hemorrhage, as observed in this case, is found in $1 \%$ of autopsies. ${ }^{32}$

LPL is an important differential diagnosis not only because of the morphological features, but also because of the presence of a paraprotein ( $\mathrm{lgG})$ and bone marrow involvement. However, in the present case, bone marrow involvement was mild. Furthermore, other features more often related to LPL were lacking, such as the involvement of the spleen and IgM paraprotein. ${ }^{33}$

lgG4-related disease is a recently described systemic autoimmune fibro-inflammatory condition characterized by tumefactive lesions, storiform fibrosis, and frequently elevated serum IgG4 levels. The closest histopathological mimickers of IgG4related disease are lymphomas; however, in contrast to B-cell lymphomas, the lymphoid inflammatory infiltrate in lgG4-related disease is composed primarily of T cells. ${ }^{34}$ Kidney manifestations of IgG4related disease include tubulointerstitial nephritis, glomerular disease, inflammatory pseudotumors and chronic sclerosing pyelitis. ${ }^{35}$ Recent reports have demonstrated a possible link between MZL and IgG4-related disease including IgG4-producing MALT lymphoma and lymphomas arising in previous IgG4 disease. ${ }^{36-39}$ The present case may represent an IgG4-producing lymphoma.

\section{CONCLUSION}

In summary, we report a rare case of a probable primary kidney MALT lymphoma with systemic dissemination diagnosed at autopsy. The early diagnosis was missed because of the lack of diagnostic suspicion. The increased volume of the salivary glands and recurrent urinary infections could have helped to raise the suspicion of an immunologic disturbance. Catastrophic Waterhouse-Friderichsen syndrome, probably related to urinary sepsis, was the immediate cause of death in this advanced stage, indolent, and underdiagnosed lymphoma.

\section{ACKNOWLEDGEMENTS}

The authors thank Dr. L. Jeffrey Medeiros for important comments and suggestions on the manuscript.

\section{REFERENCES}

1. Isaacson PG, Chott A, Nakamura S, Müller-Hermelink HK, Harris NL, Werdlow SH. Extranodal marginal zone lymphoma of mucosa-associated lymphoid tissue (MALT lymphoma). In: Swerdlow S, Campo E, Harris NL, editors. International Agency for Research on Cancer. WHO classification of tumors of haematopoietic and lymphoid tissue. Genève: World Health Organization; 2008. p. 214-7.

2. Zinzani PL. The many faces of marginal zone lymphoma. Hematology Am Soc Hematol Educ Program. 2012;2012:42632.

3. Isaacson PG, Wright DH. Extranodal malignant lymphoma arising from mucosa-associated lymphoid tissue. Cancer. 1984;53:2512-24. http://dx.doi. org/10.1002/1097-0142(19840601)53:11<2515::AIDCNCR2820531125>3.0.CO;2-C

4. Konoplev S, Lin P, Medeiros J. et al. Clonal relationship of extranodal marginal zone lymphomas of mucosaassociated lymphoid tissue involving different sites. Am J Clin Pathol. 2010;134:112-8. PMid:20551275. http://dx.doi. org/10.1309/AJCPOHT6ZGSZKNFT

5. Thieblemont C, Berger F, Coiffier B. Mucosa-associated lymphoid tissue lymphomas. Curr Opin Oncol.1995;7:415-20. http://dx.doi.org/10.1097/00001622-199509000-00005

6. Emanuele Z, Annarita C, Pedrinis E, et al. Nongastric marginal zone B-cell lymphoma of mucosa-associated lymphoid tissue. Blood. 2003;101:2489-95. PMid:12456507. http:// dx.doi.org/10.1182/blood-2002-04-1279

7. Porcaro AB, D‘Amico A, Novella G, et al. Primary lymphoma of the kidney. Report of a case and update of the literature. Arch Ital Urol Androl. 2002;74:44-7. PMid:12053451

8. Peces R, Vega-Cabrera C, Peces C, Pobes A, Fresno MF. B-cell lymphoma of MALT involving the kidney and monoclonal gammopathy: a case report with revision of the literature. Nefrologia. 2010;30:681-686. PMid:21113219. http://dx.doi. org/10.3265/Nefrologia.pre2010.Jun.10428.

9. Dogan A, Du M, Koulis A, Briskin MJ, Isaacson PG. Expression of lymphocyte homing receptors and vascular addressins in low-grade gastric B-cell lymphomas of mucosa associated lymphoid tissue. Am J Pathol. 1997;151:1361-9. PMid:9358762 PMCid:PMC1858078.

10. Brandtzaeg P, Farstad I, Haraldsen G. Regional specialization of the mucosal immune system: primed cells do not always home along the same track. Immunol Today. 1999:20:267-77. http://dx.doi.org/10.1016/S0167-5699(99)01468-1

11. Isaacson PG. Gastric MALT-lymphoma: from concept to cure. Ann Oncol.1999;10:637-45. http://dx.doi. org/10.1023/A:1008396618983

12. Raderer M, Isaacson PG. Extranodal lymphoma of MALTtype: Perspective at the beginning of the 21st century. Expert 
Rev Anticancer Ther. 2001;1:53-64. PMid:12113133. http:// dx.doi.org/10.1586/14737140.1.1.53

13. Isaacson PG. Gastrointestinal Lymphoma. Hum Pathol.1994;25:1020-29. http://dx.doi.org/10.1016/00468177(94)90060-4

14. Hyjek E, Isaacson PG. Primary B cell lymphoma of the thyroid and its relationship to Hashimoto's thyroiditis Hum Pathol. 1988;19:1315-26. http://dx.doi.org/10.1016/S00468177(88)80287-9

15. Hyjek E, Smith WJ, Isaacson PG. Primary B-cell lymphoma of salivary glands and its relationship to myoepithelial sialadenitis. Hum Pathol. 1988;19:766-76. http://dx.doi. org/10.1016/S0046-8177(88)80259-4

16. Zucca E, Bertoni F, Roggero E, et al. Molecular analysis of the progression from Helicobacter pylori-associated chronic gastritis to mucosa-associated lymphoid-tissue lymphoma of the stomach. N Engl J Med. 1998;338:804-10. PMid:9504941. http://dx.doi.org/10.1056/NEJM199803193381205

17. Jonsson V, Wiik A, Hou-Jensen K, et al. Autoimmunity and extranodal lymphocytic infiltrates in lymphoproliferative disorders. J Intern Med. 1999;245:277-86. http://dx.doi. org/10.1046/j.1365-2796.1999.0443f.x

18. Miklos JA, Swerdlow SH, Bahler DW. Salivary gland mucosaassociated lymphoid tissue lymphoma immunoglobulin $\mathrm{V}$ $(\mathrm{H})$ genes show frequent use of V1-69 with distinctive CDR3 features. Blood. 2000;95:3878-84. PMid:10845923

19. Campo E, Chott A, Kinney MC, et al. Update on extranodal lymphomas. Conclusions of the Workshop held by the EAHP and the SH in Thessaloniki, Greece. Histopathology. 2006;48:481-504. PMid:16623775 PMCid:PMC1448691. http://dx.doi.org/10.1111/j.13652559.2006.02369.x

20. Qiu L, Unger PD, Dillon RW, et al. Low-grade mucosa associated lymphoid tissue lymphoma involving the kidney: report of 3 cases and review of the literature. Arch Pathol Lab Med. 2006;130:86-9. PMid:16390244

21. Mortlock AM, Lim CSE, Morgan H, et al. Renal MALToma: an unusual lymphoma in a patient with lupus. Lupus. 2006;15:6135. http://dx.doi.org/10.1177/0961203306071920

22. Garcia M, Konoplev S, Morosan C, et al. Malt Lymphoma involving the kidney. Am J Clin Pathol. 2007;128:464-73. PMid:17709321. http://dx.doi. org/10.1309/0T2UKUKV91W3QR6W

23. Li B, Zhang W, Tian W, Qiu L. Primary renal mucosaassociated lymphoid tissue lymphoma, the result of chronic pyelonephritis? Chinese-German J Clin Oncol. 2008;7:55-8. http://dx.doi.org/10.1007/s10330-007-0148-7

24. Araki K, KubotaY, Lijima Y, et al. Indolent behavior of low-grade B-cell lymphoma of the mucosa-associated lymphoid tissue involved in salivary glands, renal sinus and prostate. Scand J Urol Nephrol. 1998;32:234-6. http:// dx.doi.org/10.1080/003655998750015665

25. Raderer M, Wohrer S, Streubel B, et al. Assessment of disease dissemination in gastric compared with extragastric mucosa-associated lymphoid tissue lymphoma using extensive staging: a single-center experience. J Clin Oncol. 2006;24:3136-41. PMid:16769982. http://dx.doi. org/10.1200/JCO.2006.06.0723

26. Asatiani E, Cohen P, Ozdemirli M, Kessler CM, Nabromatis B, Cheson BD. Monoclonal gammopathy in extranodal marginal zone lymphoma (ENMZL) correlates with advanced disease and bone marrow involvement. Am J Hematol. 2004;77:1446. PMid:15389912. http://dx.doi.org/10.1002/ajh.20157

27. Charitaki E, Liapis K, Moutzouris DA, et al. Primary renal MALT lymphoma presenting with cryoglobulinaemia. Nephrol Dial Transplant. 2011;26:3819-21. PMid:21878472. http:// dx.doi.org/10.1093/ndt/gfr478

28. Rohatiner A. Report on a workshop convened to discuss the pathological and staging classifications of gastrointestinal tract lymphoma. Ann Oncol. 1994;5:397-400. PMid:8075046

29. Thieblemont C, Bergern F, Dumontet C, et al. Mucosaassociated lymphoid tissue lymphoma is a disseminated disease in one third of 158 patients analyzed. Blood. 2000;95:802-6. PMid:10648389

30. Altman DG, De Stavola BL, Love SB, Stepniewska KA. Review of survival analyses published in cancer journals. Br J Cancer. 1995;72:511-8. http://dx.doi.org/10.1038/ bjc. 1995.364

31. Ferreri AJ, Freschi M, Dell'Oro S, Viale E, Villa E, Ponzoni M. Prognostic significance of the histopathologic recognition of low-and high-grade components in stage I-II B-cell gastric lymphomas. Am J Surg Pathol. 2001;25:95-102. http://dx.doi. org/10.1097/00000478-200101000-00011

32. Kovacs KA, Lam YM, Pater JL Bilateral massive adrenal hemorrhage. Assessment of putative risk factors by the case-control method. Medicine. 2001;80:45-53. http://dx.doi. org/10.1097/00005792-200101000-00005

33. Lin P, Molina TJ, Cook JR, Swerdlow SH. Lymphoplasmacytic lymphoma and other non-marginal zone lymphomas with plasmacytic differentiation. Am J Clin Pathol. 2011;136:195210. PMid:21757593. http://dx.doi.org/10.1309/ AJCP8FOIVTB6LBER

34. Stone JH, Zen $\mathrm{Y}$, Deshpande V. IgG4-related disease. N Engl J Med. 2012;366:539-51. PMid:22316447. http://dx.doi. org/10.1056/NEJMra1104650

35. Cornell L. IgG4-related kidney disease. Curr Opin Nephrol Hypertens. 2012;21:279-88. PMid:22487688. http://dx.doi. org/10.1097/MNH.0b013e32835265ac

36. Sato Y, Ohshima K, Takata K, et al. Ocular adnexal IgG4-producing mucosa-associated lymphoid tissue 
lymphoma mimicking IgG4-related disease. J Clin Exp Hematop. 2012;52:51-5. http://dx.doi.org/10.3960/jslrt.52.51

37. Go H, Kim JE, Kim YA, et al. Ocular adnexal IgG4-related disease: comparative analysis with mucosa-associated lymphoid tissue lymphoma and other chronic inflammatory conditions. Histopathology. 2012;60:296-312. PMid:22211288. http://dx.doi.org/10.1111/j.1365-2559.2011.04089.x
38. Venkataraman G, Rizzo KA, Chavez JJ, et al. Marginal zone lymphomas involving meningeal dura: possible link to IgG4-related diseases. Mod Pathol. 2011;24:355-66. PMid:21102421. http://dx.doi.org/10.1038/modpathol.2010.206

39. Sato $\mathrm{Y}$, Takata $\mathrm{K}$, Ichimura $\mathrm{K}$, et al. IgG4-producing marginal zone B-cell lymphoma. Int J Hematol. 2008;88:428-33. PMid:18839275. http://dx.doi.org/10.1007/s12185-008-0170-8

\section{Conflict of interest: None}

Submitted on: $16^{\text {th }}$ May 2013

Accept on: $20^{\text {th }}$ September 2013

Correspondence: Serviço de Anatomia Patológica

Hospital Universitário da Universidade de São Paulo

Av. Prof. Lineu Prestes, 2565 - Cidade Universitária - São Paulo/SP - Brazil

CEP: 05508-000 - Phone: +55 (11) 3091-9384

E-mail: aloisiosilva@hu.usp.br 